\title{
Marx i Tidsskriftet
}

Folkeforflytninger har det vært mange av opp gjennom historien - og de har hatt ulik bakgrunn. I Tidsskriftet nr. 14/1934 avslutter Trygve Braatøy sin 37 sider lange kritikk av Ørnulv Ødegårds avhandling Emigration and insanity. Ifølge Braatøy har man i Norge på grunn av «nasjonalromantisk historieforgylling med vikinger og sjørøvertokter vært tilbøielig til å la heltesagaene farve av på emigrasjonsproblemet» - det skal være «en indre - blodets - røst» som får folk til å flytte fra landet, ikke ytre omstendigheter. «Helt psykiatrisk lyder det slik hos $\emptyset$ degaard: Det er fortrinsvis de schizoide som emigrerer.» Braatøy har en mer materialistisk forklaringsmodell. Det sier litt om både tiden og lesernes dannelsesnivå at han kan sitere fra Kapitalen med henvisningen «Anno 1867 utkom det en bok som fremdeles har krav på interesse» (Tidsskr Nor Lægeforen 1934; 54: $729-37)$.

\section{Sinnssykdom og emigrasjon II.}

\section{Nogen tilleggsbemerkninger om psykiatri og sociologi.}

\author{
Av Trygve Braatøy, Oslo.
}

(Forts.)

III.

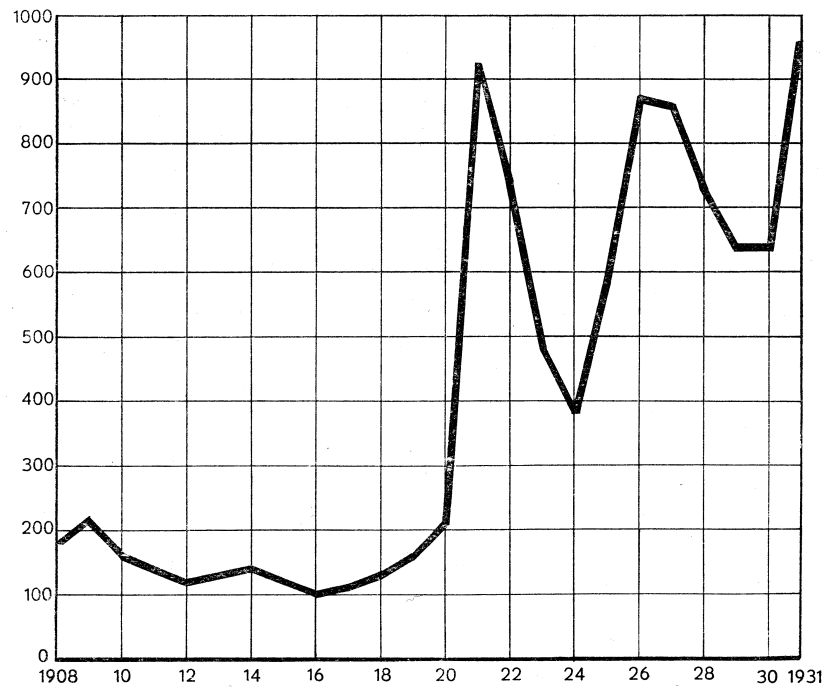

Arbeidssøkende menn pr. 100 ledige plasser ved de offentlige arbeidskontorer (årlig gjennemsnitt).

Når man skriver om emigrasjon og sinnsykdom fastholder jeg at sociologien ikke bør være altfor ukjent. Den moderne norske oversjøiske emigrasjon begynte for ca. 100 år siden. Den begynte omtrent samtidig med den industrielle tidsalder i Norge. Anno 1867 utkom det en bok som fremdeles har krav på interesse. I denne bok blev det fremholdt at den industrielle produksjonsprosess - kapitalistisk organisert - med immanent nødvendighet vil skape et permanent arbeidsløst proletariat, en industriell reservearmé. Denne reservearmé vil alltid være rede til å vandre dit hvor den bys arbeide ${ }^{1}$ ).

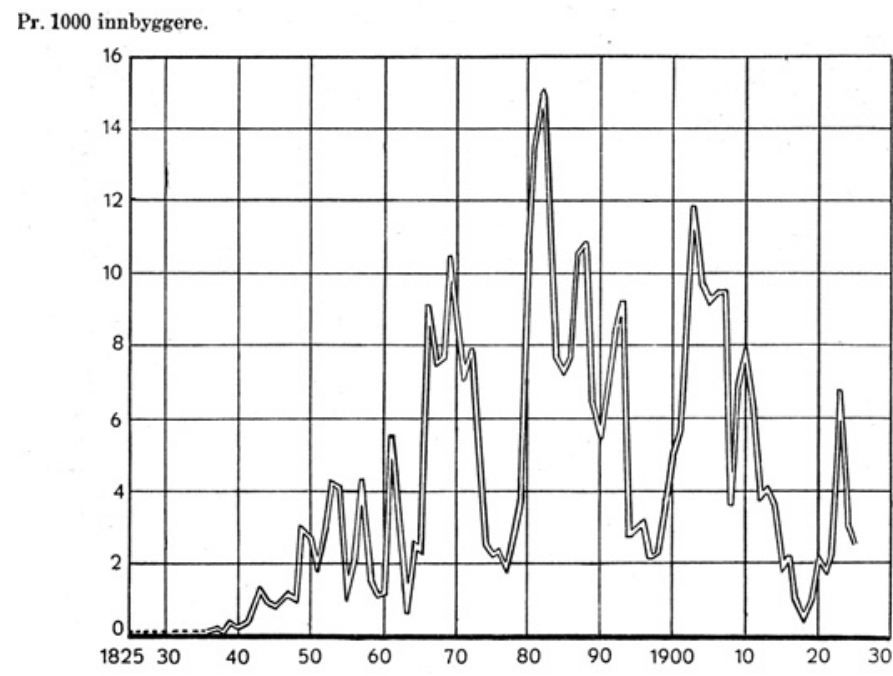

Oversjøisk utvandring fra Norge 1836-1925. (Norges off. stat. VII 25, VIII 6).

Det er så å si dens kapitalistiske funksjon. Hvordan stemmer denne dogmatikk fra 1867 med forholdene i Norge? Selv i de eksepsjonelt gode år under krigen var de norske fagforeninger belastet med permanent arbeidsløshet. Det stemmer også med de subjektive oplysninger. Også i de år angir en del av utvandrerne «manglende adgang til lønnende virksomhet» som utvandringsgrunn. Sammenlignet med de dårlige tider er antallet forsvinnende, men de objektive og subjektive data stemmer altså innbyrdes.

1) F. eks. fra Rjukan til Herøya. 